\title{
Electrolyte and body water changes after trauma
}

CECIL T. G. FLEAR

From the University Department of Clinical Biochemistry, Royal Victoria Infirmary, Newcastle upon Tyn

It has been known for a long time now that patients commonly gain sodium and chloride after injuries and surgery. It is also well known that despite this fact, the level of sodium in extracellular fluid very often falls, and is ascribed to a relatively greater gain of water than of salt, with resulting dilution of body fluids. However, the not uncommon associated rise in potassium and bicarbonate levels is difficult to reconcile with simple dilution. We know too that patients lose potassium after trauma and that more is lost than might be expected to be brought about by the 'catabolism' of tissue which trauma provokes.

Why these changes arise is much less certain than that they do. The gains of sodium and chloride, and also the losses of potassium, are usually held to be brought about by altered kidney activity in turn caused by increased production of aldosterone. Imbalance between protein anabolism and catabolism is said to be produced by increased secretion of glucocorticoids. But surgery in patients previously adrenalectomized provokes the same gains of $\mathrm{Na}$ and $\mathrm{Cl}$ and losses of $\mathrm{K}$ and nitrogen even though the patients receive the same maintenance dose of steroid after surgery as before.

There is uncertainty too about the extent and nature of any change in the volume of extracellular fluid during and after trauma. From dilution studies, variously carried out, some have concluded that the volume of extracellular fluid expands, others that it shrinks, others that it remains unchanged.

I think that present uncertainties on all scores arise from inadequacies in our knowledge of cellular happenings provoked by trauma-of their nature and of their consequences. Measurements show that cardiac output falls during surgery (McNeill and Mackenzie, unpublished observations), even when every attempt is made fully to replace blood as it is lost, and whện indices such as central venous pressure, system blood pressure, pulse rate, and measurement of blood loss on swabs suggest that this has be achieved. Moreover, even uncomplicated surge 9 is accompanied by hypoxia (Nunn, 1965; Nurn and Freeman, 1964). This, together with impaired or altered tissue perfusion from blood loss, ex, is likely to provoke widespread cell changes which, with directly incurred local tissue call damage, may be largely responsible for the accumulation of $\mathrm{Na}, \mathrm{Cl}$, and water, for loss \&f potassium, for hyponatraemia, and for other changes in the composition of extracellular fluid, and possibly also for the imbalance between tissie protein anabolism and catabolism. Postoperative complications, such as further blood loss, i⿱日一-口flammatory accumulation of protein and flugd in the peritoneum or elsewhere, infection and sepsis, will directly or indirectly accentuate the cellular changes and so the changes in body water and electrolytes.

\section{Regulation of Body Water and Electrolytes 恋 Health}

Most of our body water is inside cells. Somecis outside (Fig. 1,1). Virtually all is osmotica hy available (Bernal, 1965; Olmstead, 1966; Netter, 1969), dissolving solutes, so that it is present throughout effectively as a dilute solution whigh is stirred (Fig. 1,2) by the circulation (Table (q) and by diffusion across capillary walls, through interstitial fluid, across outer cell membranes, and within cells. Over the very short distances involved (cell diameter $20-50 \mu$; cell to capillarg, approximately $25.4 \mu$ ) diffusion will ensure virtually instantaneous mixing (Robinson, 196\%; 

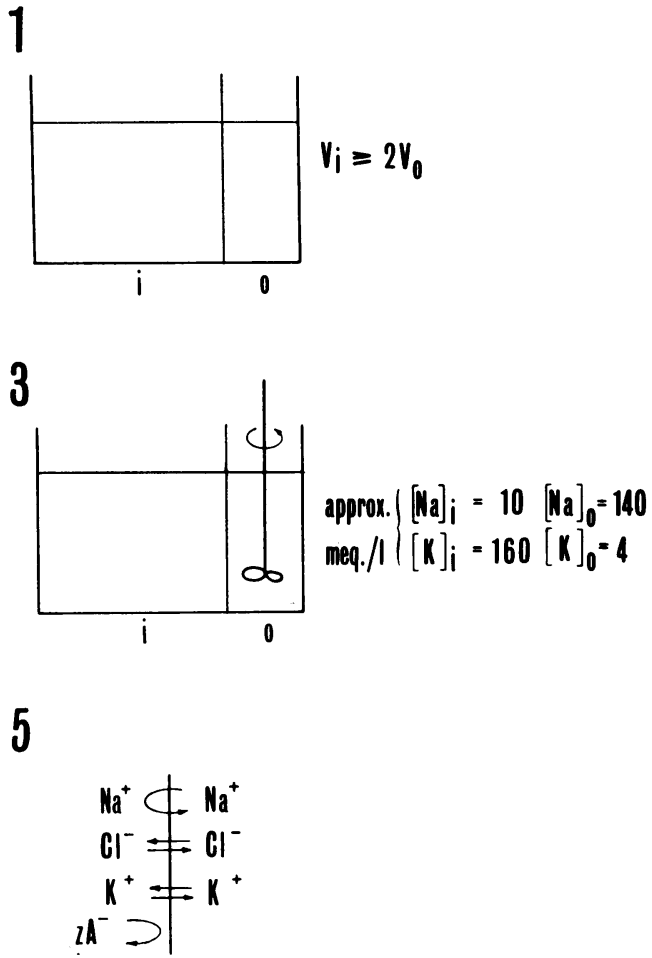

Fig. 1 Simplified presentation of the most important features of water and electrolyte balance.

Landis and Pappenheimer, 1963; Langer, 1968). ${ }^{1}$ Fluid inside cells has the same osmolality as that outside. Osmotic transients which arise during the course of metabolic activity are cancelled by appropriate shifts of water which diffuses into and out of cells vastly more quickly than solutes (Robinson, 1965).

The principal solutes in body fluids are salts of $\mathrm{Na}$ and $\mathrm{K}$. These two cations and their anions have, however, an asymmetrical distribution between fluid inside and outside cells (Fig. 1,3).

All gain water and electrolytes in food and drink and all lose both in urine, faeces, and sweat. Water is of course also produced within cells as a result of cellular respiration and lost through the lungs and in insensible perspiration. Nevertheless, so long as adults are healthy the amounts of both water and electrolytes in the body are

${ }^{1}$ It can be calculated (after Jacobs, 1935) that for a solute diffusing into a pure solvent from the plane boundary of a solution maintained at a fixed composition, the concentration $25.4 \mu$ from the boundary should reach $99 \%$ of its steady state value in 0.294 seconds. In this time, and under resting conditions, plasma flow through $100 \mathrm{~g}$ of skeletal muscle would be approximately $1.5 \times$ $10^{-2} \mathrm{ml}$.

Landis and Pappenheimer (1963) have calculated that by diffusion plasma water exchanges 120 times per minute with the interstitial water immediately surrounding the capillaries (for $\mathrm{K}$ and $\mathrm{Na}$, the corresponding exchanges are 90 and 60 times plasma content). Alternatively these exchanges amount respectively to 40,30 , and 20 times the resting plasma flow in skeletal muscle. (Clearance is less.)
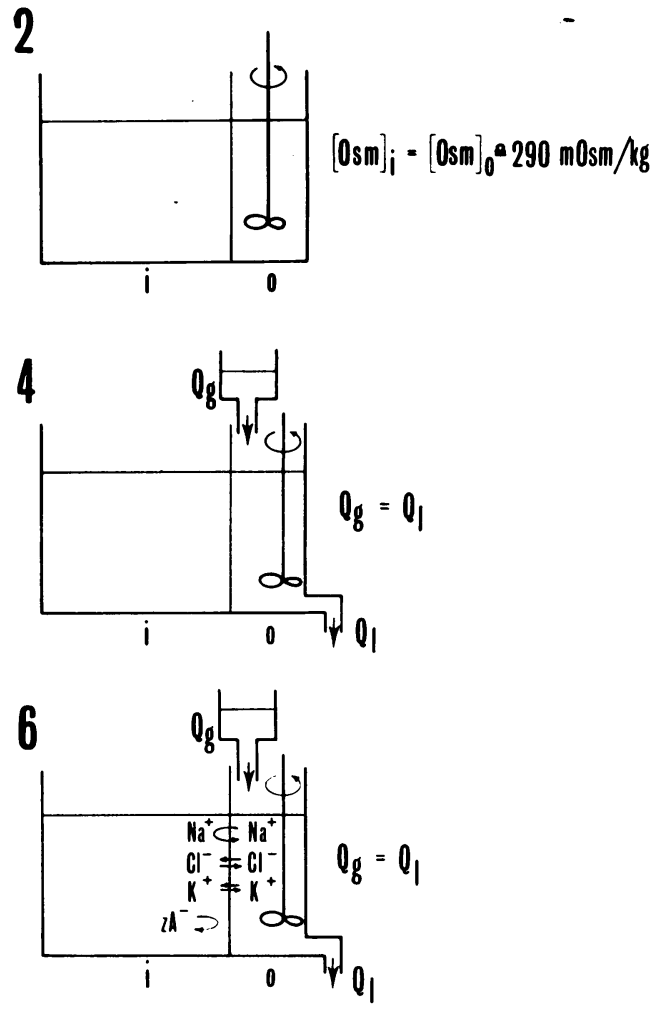

fairly constant week in week out. This constancy is dynamically attained from adjustment of losses in urine in the light of various gains and the various other losses in sweat, faeces, and so on (Fig. 1,4). Constancy is achieved in a stepwise fashion. Small deficits provoke net gains and vice versa. The kidneys are assisted in this process by a number of neurohumoral servomechanisms which signal shortages or excesses and their cancellation.

But self maintenance of body fluids entails more than simply balancing the quantities gained and lost. This alone would not preserve the asymmetrical distribution of $\mathrm{Na}$ and $\mathrm{K}$ in body fluids; nor would it ensure that the volumes of extra- and intracellular fluid remain fairly

\begin{tabular}{lll}
\hline & $\begin{array}{l}\text { Plasma Flow } \\
\text { per Minute }\end{array}$ & $\begin{array}{l}\text { Multiples of } \\
\text { Extracellular } \\
\text { Fluid per } \\
\text { Minute }\end{array}$ \\
\hline $\begin{array}{l}\text { Cardiac output at rest } \\
\text { Skeletal muscle blood flow }\end{array}$ & 3.0 & $0.22^{1}$ \\
$\begin{array}{l}\text { At rest } \\
\text { During vigorous exercise }\end{array}$ & 0.6 & $0.10 \mathrm{r}^{2}$ \\
\hline
\end{tabular}

Table I Movement of body water in healthy adults

${ }^{1}$ Extracellular fluid $\mathbf{1 4} \cdot \mathbf{1}$

${ }^{2}$ Extracellular fluid $=20 \%$ wet muscle weight.

${ }^{3}$ Wade and Bishop (1962) 
constant, which they both do, in the face of the continual interchange of water and ions that takes place between fluid compartments.

\section{Attainment of Cell Balance and Its Significance for Homeostasis}

Constancy in the total volume of intracellular fluid derives from the separate regulation of the volume of fluid in each of the millions of cells within the body. This is achieved as a result of each cell keeping its total solute content constant. And this involves attaining a balance between (1) the rate at which $\mathrm{Na}$ leaks into cells from the extracellular fluid and the rate at which it is actively transported, or pumped out again (Post and Jolly, 1957; Robinson, 1960, 1965; Tosteson and Hoffman, 1960; Tosteson, 1964; Stein, 1967) and (2) the metabolic production and 'disposal' of non-diffusible organic solutes.

The way in which both balances are achieved has been little studied. Possibly in man the latter balance derives largely as a byproduct of regulation of cell metabolism. But it is known that change in osmolality of extracellular fluid in certain euryhaline inhabitants of estuaries (caused by the changing tides) provokes specific changes in metabolism which drastically alter the amounts of organic solutes in cells, so that the osmolality of cell fluids also changes and in a parallel direction (Brown and Stein, 1960; Lockwood, 1963; Potts and Parry, 1964; Schoffeniels, 1967). This minimizes the shifts of water between extraand intracellular fluid caused by the change in osmolality of extracellular fluid, and Wolf and his colleagues (McDowell, Wolf, and Steer, 1955) have suggested that similar changes may take place in response to fluctuation in osmotic pressure of extracellular fluid in the cells of terrestrial animals.

The way in which the $\mathrm{Na}$ pumps are regulated is poorly understood (Mullins and Frumento, 1963; Woodbury, 1963, 1965; Mullins and Awad, 1965; Langer, 1968). They are, however, collectively responsible for the asymmetrical distribution of $\mathrm{Na}$ and $\mathrm{K}$ throughout the body. ${ }^{1}$ They are also partly responsible for regulating the overall daily balance of $\mathrm{K}$, for the amount of $\mathrm{K}$ in each cell, and so in the body as a whole, is determined by the quantity of non-diffusible anions $\left(\mathrm{zA}^{-}\right)$it contains (Fig. 1,5). Conway (1957) considers that the anions which require $\mathrm{K}$ as counterions, are largely metabolites such as ATP, creatine phosphate, hexose, and triose

\footnotetext{
${ }^{1}$ Why cells possess $\mathrm{Na}$ pumps rather than $\mathrm{K}$ pumps is of course an intriguing point. It is perhaps relevant that, since cells are normally some 50 to 100 times more permeable to $K$ than $\mathrm{Na}$ (probably because the hydrated $\mathrm{Na}$ ion is larger than that of $\mathrm{K}$ (Conway, 1957), although see Mullins, 1959, 1960; Diamond and Wright, 1969), pumping $K$ out from cells as fast as it diffused in from the extracellular fluid would require a greater expenditure of energy than pumping out $\mathrm{Na}$.
}

phosphates. Ling, on the other hand, suggests (Ling and Ochsenfeld, 1966) that $\mathrm{K}$ acts as counterions to negative charges on structural proteins. If $\mathrm{Na}$ accumulates in a cell, less $\mathrm{K}$ is needed to maintain electrical neutrality. The other main factor determining the amount of $\mathrm{K}$ in cells (and in the body) is the balance between production and disposal of non-diffusible organic solutes, since many of these are polyvalent anions.

Thus, the overall daily balance of $\mathrm{K}$ as well as water derives from the balance attained at the cell level. The kidneys play a subservient role: they get rid of unavoidable dietary gains. ${ }^{2}$ But since $\mathrm{K}$ enters cells and is not extruded, it is not immediately obvious why the daily provision of $\mathrm{K}$ and diffusible anions fails to provoke a progressive accumulation within cells. It can, however, be shown that unless there is an increase in the quantity of non-diffusible anions in cells, for cells to gain a substantial amount of potassium is only possible if there is a very marked increase in the level of $\mathrm{K}$ in extracellular fluid. This is prevented by the spilling of $K$ in urine, which is probably brought about by an increased secretion of aldosterone triggered by a rising level of $\mathrm{K}$. The first observed effect when very small amounts of aldosterone are infused is on the excretion of $\mathrm{K}$ rather than of $\mathrm{Na}$ (Ross, 1965).

In contrast, the kidneys normally play the dominant role in maintaining a constant body content of $\mathrm{Na}$. In this they are guided by neurohumoral servomechanisms activated by change in volume of extracellular fluid. Probably the most important factor here is the so-called 'third factor'. This increases in response to expansion of extracellular fluid and brings about an increase in urinary loss of $\mathrm{Na}$. Shrinkage of extracellular fluid provokes a decrease in the 'third factor' and also increases secretion of aldosterone; excretion of $\mathrm{Na}$ is lessened. But for $\mathrm{Na}$, too, inasmuch as general body cells normally actively extrude $\mathrm{Na}$ as fast as it leaks in from the extracellular fluid, cell balance can be considered to play a part in the regulation of body content. By the same token, in achieving a balance of $\mathrm{Na}$ and in the molar quantity of non-diffusible solutes constrained within them, the body's cells contribute towards maintaining a fairly constant volume of extracellular fluid.

In a balanced state there are at least three equilibria across all cell membranes and within fluids: (1) osmotic equilibrium, (2) electrical neutrality, and (3) double Donnan equilibrium.

\footnotetext{
${ }^{2}$ The foods eaten by man are mostly plant and animal tissues or products made from them. Possibly not all urinary losses of $\mathrm{K}$ arise as spillage of unavoidable dietary gains. There is, for instance, good evidence that first thing in the morning muscles lose a substantial amount of $\mathrm{K}$ (Andres, Cader, Goldman, and Zierler, 1957). Of course these and any other losses that may arise will be corrected promptly because the cells still have the usual amount of anions. With $\mathrm{K}$ available from the diet, cells simply eject the excess of $\mathrm{Na}$ that accumulated to balance the deserted anions, and $\mathrm{K}$ is attracted into them by the electrical gradient created during the process of extrusion.
} 
Their resolution ${ }^{1}$ in the light of overall daily balances, and the outcome of exchanges between cells and extracellular fluid are responsible for setting the composition of extracellular fluid. The relative constancy of this composition in health derives as much therefore from the activity of general tissue cells in resolving their individual balance problems as from the kidneys in regulating overall balance (Fig. 1,6). At rest about $80 \%$ of the blood ejected with each beat of the heart goes elsewhere than to the kidneys. During exercise this proportion increases substantially. Just as cells help to keep the concentration of hydrogen ions fairly constant in extracellular fluid, so too they absorb the first impact of change in other components of extracellular fluid thereby damping down any such change. For instance, a net loss of $\mathrm{K}$ from one tissue will provoke an increase in the level of $\mathrm{K}$ in blood leaving it, and so in blood which is supplied to other tissues. Cells in these other tissues in the process of coming into equilibrium with the new extracellular fluid levels will gain some $\mathrm{K}$, thereby reducing its level. To some extent such changes take place during normal activity. Muscle cells, for instance, gain $\mathrm{Na}$ and lose $\mathrm{K}$ when they contract. Changes in metabolism are likely to alter the steady state levels of non-diffusible intermediates, and so to provoke net shifts of water and $\mathrm{K}$. But these changes are not sustained, nor are they likely at any one time to involve much tissue in a concerted fashion. In a sense they may be considered to be stochastic, and this will result in their being at least partly self cancelling. For instance, muscles are not used at the same time, and in those being used, muscle fibres do not all contract and relax in unison. Some relax whilst others contract, so that some cells will be gaining K whilst others are losing it (Flear, 1967).

\section{Imbalance at the Cell Level and Its Consequences}

Sustained imbalance causes a cell to gain, or lose, water and ions, and, when enough cells are involved, a substantial change in body content will result. Abrupt changes will also alter the volume of extracellular fluid.

Normally, the actual composition of extracellular fluid fluctuates about a point of balance as a result of net exchanges of water and ions across cell membranes in response to the exigencies of tissue function and metabolic activity. This will also be the case when a new balanced

\footnotetext{
${ }^{1}$ In view of its complexity the outcome of simultaneous resolution of these equilibria in response to a given perturbation is not always immediately obvious. But equations can be derived which express the requirements for each of the separate equilibria. They can be combined in various ways (Boyle and Conway, 1941; Conway, 1945, 1957; Leaf, 1956; Adrian, 1960; Brown and Stein, 1960) to give a number of additional equations that predict the outcome of changes.
}

state has been established. When, however, imbalance involves progressively more cells, or becomes progressively more marked, the composition of the extracellular fluid will show progressive changes. In labile situations with rapid alterations in the extent or direction of imbalance in affected cells, or in the number of cells involved, the volume and composition of extracellular fluid will oscillate markedly about a rather tenuous point of balance.

\section{Cellular Happenings}

When Na leaks into cells faster than it is baled out cells accumulate $\mathrm{Na}, \mathrm{Cl}$, and water. At the same time they will lose $\mathrm{K}$. The more abnormally permeable the membranes, the less potassium will be lost during the early stages of the changing state and the more the cells will swell. When a balanced state is re-established with cells neither gaining nor losing overall there is a substantial residual loss of $\mathrm{K}$ and only a slight net gain of water (Stein, 1967).

When cells swell abruptly at the expense of extracellular fluid, that fluid shrinks. The level of $\mathrm{Na}$ in extracellular fluid will not change, since cells have gained virtually isosmotic $\mathrm{NaCl}$, unless cell membranes are so leaky that hitherto nondiffusible molecules escape into the extracellular fluid. When this happens the level of $\mathrm{Na}$ throughout the extracellular fluid $[\mathrm{Na}]_{0}$, will fall and there will be hyponatraemia (Singh and Flear, 1968). The reason for the fall is that in this situation less water will be gained by cells than in the former, and so the saline that is gained will have a higher $\mathrm{Na}$ level than that in the extracellular fluid. Osmolality will not fall. There has been neither loss of solute from the body, nor dilution of body fluids from gain of water. The volume of extracellular fluid still shrinks when this happens but to a lesser extent.

If at the same time that cells accumulate $\mathrm{Na}$, more solutes are generated within cells which then escape through leaky membranes, cells will still swell and the extracellular fluid shrink. Hyponatraemia, too, still develops.

In all of these situations the level of $\mathrm{K}$ throughout the extracellular fluid is not diluted. On the contrary hyperkalaemia is extremely likely to develop. Accumulation of saline within cells increases the concentration of chloride in cell fluid. The product of the concentrations of $K$ and chloride thereupon rises. For the establishment of a new balanced state across cell membranes, the similar product of these concentrations in extracellular fluid must rise, since in a balanced state these two products are equal, as a consequence of a double Donnan equilibrium (equation 3, Appendix). In the presence of an hyponatraemia the level of chloride in extracellular fluid must be low, and so an increase 


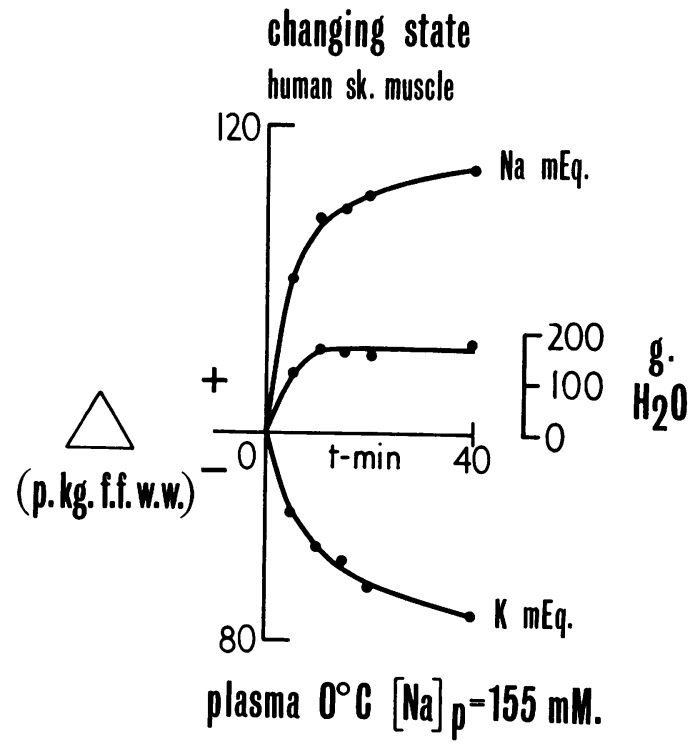

Fig. 2 Gains of $\mathrm{Na}$ and water and loss of $\mathrm{K}$ by pieces of human skeletal muscle during the first 40 min after immersion in cold plasma $\left(0^{\circ} \mathrm{C}\right)$. Ten pieces of rectus abdominis (20-50 $\mathrm{mg}$ ) from a given person were put into plasma taken from the same person. Duplicates were removed at each of the specified time intervals. The experiment was repeated using samples from six patients. Values are thus each the mean of 12. The level of $\mathrm{Na}$ in all plasmas was brought to $155 \mathrm{mM}$ by addition of the appropriate volume of $\mathrm{MNaCl}$. Gains and losses in each patient were calculated by comparing with average composition of six samples not immersed in plasma.

Data from Flear and Rajasingham (1969).

in the ' $\mathrm{KCl}$ product' is achieved by an increase in the concentration of $K$.

The consequences of imbalance between leak and pump rates can be predicted from what is known of the factors governing the partition of water and ions in tissues. Knowledge of these factors has been derived largely from studies of frog skeletal muscle, squid nerves, and so on in vitro. But it has been shown to apply to tissues from other animals and to situations in situ (Küsel and Netter, 1952; Lukowsky and Netter, 1952; Mond, 1955) as well. Many of us consider that this understanding is directly relevant to human tissue also, and Fig. 2 shows what happens to pieces of human rectus abdominis when imbalance between influx and reflux of $\mathrm{Na}$ is provoked by putting them into human plasma at $0^{\circ} \mathrm{C}$. In this situation there is also an increase in organic anions $\left(\mathrm{zA}^{-}\right)$in the tissue, so that pieces show rather more residual gain of water than they would otherwise.

The various situations considered above were selected because anoxia, in addition to impairing $\mathrm{Na}$ pumps, is known to provoke breakdown of

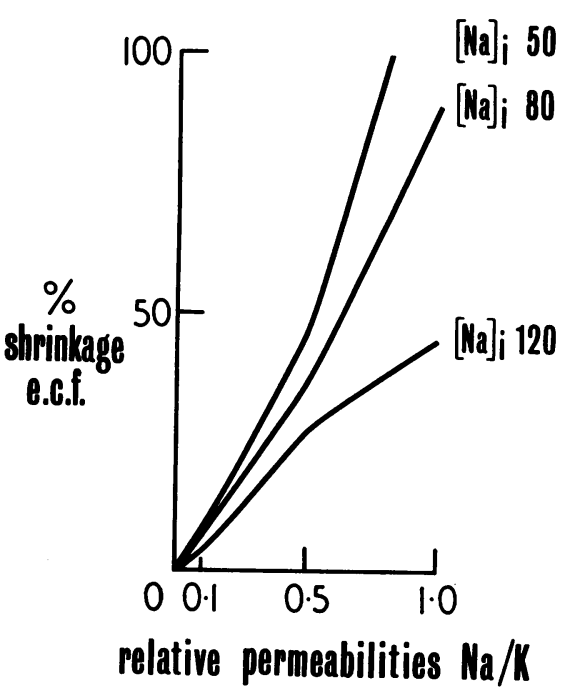

Fig. 3 Shrinkage of extracellular fluid during abrupt swelling of cells caused by imbalance between the rate at which $\mathrm{Na}$ leaks into cells and the rate at which it is actively transported out again (see Appendix for details of calculation).

Cells swell more when the permeability of their membranes increases, indicated by an increase in the ratio of permeabilities towards $\mathrm{Na}$ and $\mathrm{K}$. In the examples shown, 10, 20, and 30\% of the body's cells are assumed to sivell. It is further assumed that these cells can pump Na at a rate just insufficient to balance the passive influx when the Na concentration in cell water is 120,80 , and 50 m-equiv per litre respectively. A concentration of $\mathrm{Na}$ in extracellular fluid of 140 m-equiv per litre is assumed.

compounds such as ATP and creatine phosphate. thereby increasing the molar quantity of solutes within cells. It is also known to increase permeability of cell membranes with resultant escaße of some, at any rate, of the breakdown products.

Effects of Abrupt Imbalance on Volume of Extr危 cellular Fluid

It is possible to go further and to calculate the sort of impact that abrupt and extensive cellular swelling will have on the volume of extracellufar fluid.

During the changing state of $\mathrm{Na}$ gain, electrical neutrality is maintained in intra- and extrgcellular fluid, and in the fluid shifting from one compartment to the other. Osmotic equilibriu角 is also maintained. On the other hand, the potential across outer membranes of cels involved is a diffusion potential rather than $a$ Donnan potential. These conditions also can $\mathrm{ke}$ embodied in suitable equations which can 
changing state

$[\mathrm{Ha}]_{\mathrm{i}}=120: 10 \%$ cells

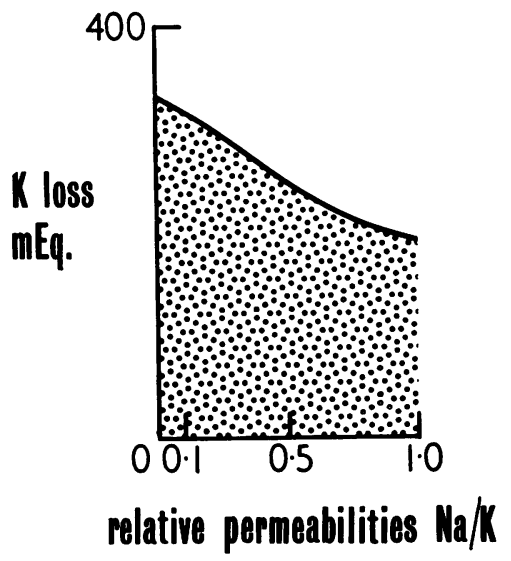

Fig. 4 Potassium loss calculated to accompany swelling of $10 \%$ of the body's cells. It is assumed that affected cells can only pump Na at a rate just less than the influx from an external concentration level of 140 to an internal concentration of 120 m-equiv per litre.

\begin{tabular}{llll}
\hline $\begin{array}{l}\text { Percentage } \\
\text { Skeletal Muscle }\end{array}$ & $\begin{array}{l}\text { Weight of } \\
\text { Skeletal Muscle } \\
(\mathrm{kg})\end{array}$ & $\begin{array}{l}\text { Extracellular } \\
\text { Fluid of } \\
\text { Skeletal } \\
\text { Muscle }(\mathrm{kg})\end{array}$ & $\begin{array}{l}\text { Calculated } \\
\text { Shrinkage of } \\
\text { Extracellular } \\
\text { Fluid }(\mathrm{kg})\end{array}$ \\
\hline 20 & $5 \cdot 88$ & $1 \cdot 18$ & $\begin{array}{l}3.3 \mathrm{~kg}[\mathrm{Na}]_{\mathrm{i}} \\
=120\end{array}$ \\
100 & 29.4 & $5 \cdot 88$ & $\begin{array}{l}2.2 \mathrm{~kg}[\mathrm{Na}]_{1} \\
=80\end{array}$
\end{tabular}

Table II Calculated shrinkage of extracellular fluid when $10 \%$ of body cells swell abruptly as result of imbalance between influx and efflux of $\mathrm{Na}^{1}$

${ }^{1}$ For comparison the volume of extracellular fluid is shown in $20 \%$ of the body's skeletal muscle mass (this corresponds to $10 \%$ of body's cells) and in the whole of skeletal muscle mass.

Skeletal muscle $=42 \%$ body weight, body weight $=70 \mathrm{~kg}$, and extracellular fluid $=20 \%$ wet weight.

combined (Appendix) so that it becomes possible to predict the change in the volume of fluid in cells, their content of $\mathrm{K}$, and so on. In this way we can calculate the sort of shrinkage in the volume of extracellular fluid that would accompany the abrupt onset of imbalance involving 10 , 20 , and $30 \%$ of the body's cell mass.

The results of our calculations are shown in Figure 3. They reveal that the more abnormally permeable cell membranes are the more cells swell and so the more the extracellular fluid shrinks. If $30 \%$ of the body's cells are involved the extracellular fluid shrinks to about one half of its normal volume: when permeability is increased and $\mathrm{Na}$ pumps can only sustain pumping at a rate nearly equal to the passive influx that would obtain when the concentration of $\mathrm{Na}$ in extracellular water $[\mathrm{Na}]_{0}$ is 140 ; in cell water
$[\mathrm{Na}]_{\mathrm{i}} 50 \mathrm{~m}$-equiv/litre. The loss of $\mathrm{K}$ that would result if $10 \%$ of the cell mass were involved is shown in Figure 4. It is substantial.

Swelling to the extent shown in Fig. 3 could, if only skeletal muscle were involved, take place at the expense of its own tissue extracellular fluid but only if the cells involved were diffusely distributed throughout the whole of the skeletal muscle mass in the body (Table II). However, even were this the case, the shift of water from interstitial fluid into cells would increase the concentration of protein in interstitial fluid, sufficiently to provoke transfer of fluid from capillaries and so to shrink the plasma volume. ${ }^{1}$ If these changes are abrupt it is unlikely that the plasma will be re-expanded at the expense of interstitial fluid in unaffected tissues since a rapid fall in plasma volume will provoke circulatory deterioration. The impact of this on the balance of forces responsible for the regulation of the exchange of fluid across the capillary in various tissues cannot be predicted.

\section{Findings after Trauma Explained by Such Cellular Events}

In my opinion cellular events such as those just described could account for all the changes in body water and electrolyte that arise after trauma. If this is so, present uncertainties concerning these changes resolve.

If gains of $\mathrm{Na}$, chloride, and water and losses of $\mathbf{K}$ after trauma are direct consequences of imbalance in the exchange of water and solutes between cells and the fluid bathing them, the fact that such changes arise after surgery in persons previously adrenalectomized and maintained on constant dosage of cortisone and in patients receiving an aldosterone antagonist does not call for special comment. In all patients cell imbalance is the direct outcome of factors increasing the permeability of cell membranes, depressing $\mathrm{Na}$ pumping, or altering the molar quantity of nondiffusible solutes constrained within cells and in the balance of anionic and cationic charges on these solutes. These events are not dependent upon increased production and release of aldosterone or cortisone, and it is unnecessary to speculate on a 'permissive' role played by these steroids in events after trauma. The increase in aldosterone seen after trauma in persons with intact adrenals is secondary to shrinkage of extracellular fluid caused by cellular swelling, inadequate replacement of blood lost, and so on.

${ }^{1}$ If skeletal muscle cells abruptly gain $3.3 \mathrm{~kg}$ water (Table II), and if interstitial fluid is initially $5.5 \mathrm{~kg}$ (extracellular fluid less plasma volume where plasma volume is $1 \%$ wet weight) the final interstitial fluid will drop to $2.2 \mathrm{~kg}$. If the level of albumin in interstitial fluid was initially $1.4 \mathrm{~g}$ per $100 \mathrm{ml}$ it would become $(5.5 / 2.2) 1.4 \mathrm{~g}$ per $100 \mathrm{ml}$. Its protein osmotic pressure would then change from approximately $4 \mathrm{~mm} \mathrm{Hg}$ to $12 \mathrm{~mm} \mathrm{Hg}$ (see Fig. 3,1 of Landis and Pappenheimer, 1963). 
It neither initiates nor is it responsible for retention of $\mathrm{Na}$, chloride, and water, or for loss of $\mathrm{K}$ although it reinforces these events. The effects of adequate blood replacement in abolishing retention of $\mathrm{Na}, \mathrm{Cl}$, and water and in lessening losses of nitrogen etc (Flear and Clark, 1955) are attributable in part to preventing or switching off the secondary hormonal response but largely to its direct effect on tissue perfusion.

There are good reasons for believing that loss of nitrogen too is an outcome of cell swelling, rather than the result of increased release of cortisone. It is known that certain euryhaline animals excrete more nitrogen when the cells swell in response to an increase in the fresh water of their surroundings (Schoffeniels, 1967). Loss of nitrogen from slices of tissue in vitro is also known to be closely related to uptake of fluid by their cells (Adrian, 1960; Aebi, 1952 and 1953). We do not know whether the increased loss of nitrogen which follows trauma derives from increased protein catabolism or diminished protein anabolism. Certainly, as Christensen (1948) first pointed out, a fall in the concentration of amino acids in cell fluid would be expected to lessen anabolism and the concentration of amino acids will fall when cells swell for several reasons, namely, dilution from gain of water, diminished ability of cells to accumulate amino acids when $\mathrm{Na}$ pumping is impaired, and some escape from cells through abnormally leaky membranes. Just as the increased secretion of aldosterone may be provoked by cellular happenings after trauma, it seems possible that release of cortisone may be provoked by a transient fall in blood glucose due to its entering cells whose membranes have become unusually permeable. ${ }^{1}$

It is difficult to account for the abrupt onset of the hyponatraemia sometimes seen on any other basis. This is true also of the rise in $\mathrm{K}$ level which not uncommonly accompanies a marked fall in plasma $\mathrm{Na}$. The coexistence of $\mathrm{Na}$ retention and fall in plasma $\mathrm{Na}$ is no longer paradoxical, nor is it necessary to suppose that there was a still greater gain of water. In many instances associated loss of weight has caused this latter assumption to appear doubtful. Others as well as myself have seen marked swings in plasma levels of $\mathrm{Na}, \mathrm{K}$, and chloride after major surgery or injuries unaccountable for by variations in gains or losses of water or electrolyte. In my experience these are most likely to arise where complications supervene. They may take place over a matter of hours or over a period of several days. These findings have no longer to be ignored or dismissed as 'laboratory error'.

The differing and apparently contradictory findings that have been reported concerning changes in the volume of extracellular fluid after

\footnotetext{
${ }^{1}$ Egdahl, Mack, and Herman (1969) consider hypovolaemia to be the best stimulus for increased secretion of ACTH. They find that endotoxins also stimulate but less consistently.
}

trauma (Flear, McNeill, Greener, and Singh, 1969a) are seen to derive partly from the fluctuztions in this volume at different times after trauma, since events after trauma are dynamic, and measurements by different investigators have not all been made at the same time. In part the derive also from methodological considerations. Variable increase in membrane permeabilify means that markers used to measure the volume of extracellular fluid may now penetrate in cells and may also take longer to equilibrafe within the body. Different investigators have not all used the same marker; nor indeed have the्s allowed the same period for equilibration.

Singh's investigations (1965) of patierifs severely ill with intestinal obstruction established (1) that on admission two to nine days after onset the thiocyanate space was commonly raised (11 of 13 patients). These patients had all been at home untreated and taking little or nothing by mouth; clinically they were dehydrated and one would therefore have expected the volume of extracellular fluid to be low. (2) After operation the thiocyanate space rose still further in 11 of 13 patients. The increase exceeded any gain $\overrightarrow{8} f$ weight over the same interval. Some did not gain weight. It seems probable, as Singh suggested that the thiocyanate space in these patients overf estimates the volume of extracellular space due to its entering into cells as a result of cell mero branes being abnormally permeable. Singh (196 also found substantial increases (from 2 to $7 \mathrm{~kg}$ ) in thiocyanate space during the first 24 hours after. other major operations. These increases were some 2.5 to $4 \mathrm{~kg}$ in excess of the carefully me $\overrightarrow{\mathrm{B}}$ sured water balances over the same 24-hour period. ${ }^{2} \mathrm{He}$ interpreted these findings similarl

Hinton and Allison (1969) have found thait intravenous infusions of insulin and glucose significantly reduce protein breakdown ang potassium loss in severely burnt patients, an promote large diureses of $\mathrm{Na}$ and chloride. The suggest that these effects result from the action of insulin in enhancing $\mathrm{Na}$ extrusion from celts (Kernan, 1962) and causing them to gain $\vec{F}$. Glucose alone is ineffective. These finding would be difficult to explain otherwise.

\section{Direct Evidence for Cellular Events after Trauma}

There is more direct evidence for the occurrence of these cellular happenings after trauma.

EVIDENCE FROM TISSUE COMPOSITION Collectively, skeletal muscle comprises some 50 \& of the body's cell mass. It must therefore involved in any major change in the content of

${ }^{2}$ Water balance was determined as intake minus urine plos 1.5 litres (estimated insensible loss and evaporative water 105 from viscera during operation). No allowance was made for water. of metabolism. 


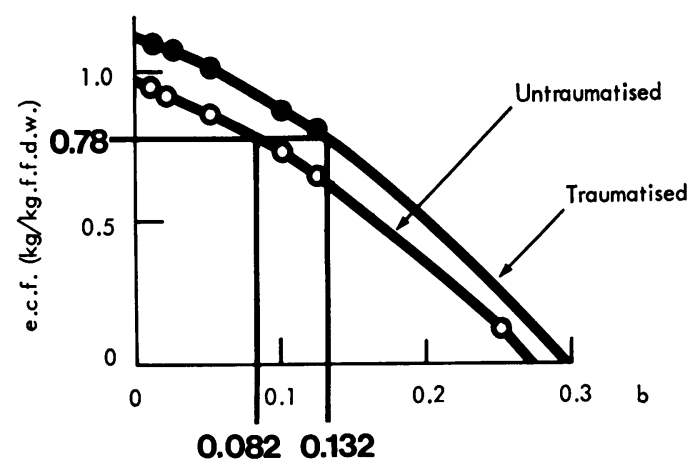

Fig. 5 Calculated average values for extracellular fluid in muscle taken at the end of operation from 10 patients undergoing major surgery.

The calculated average value (equation 8, Appendix) for extracellular fluid in biopsies taken at the beginning of operation was $0.78 \mathrm{~kg}$ per $\mathrm{kg}$ fat-free dry weight of tissue. Values for extracellular fluid at the end of operation were calculated using equation 9 (Appendix) and assuming values for $b$ (the ratio of the permeabilities PNa/PK) of 0.01 (normal) and $0 \cdot 02,0 \cdot 05,0 \cdot 10,0 \cdot 125,0 \cdot 25$ (increased permeability of cell membranes to sodium).

water and electrolyte in the body. Moreover, the composition and volume of extracellular fluid will only be altered after trauma as a result of perturbation in cell metabolism or increase in the permeability of cell membranes, if a substantial mass of tissue is so affected. Muscle would almost certainly have to be implicated in such changes. We therefore analysed skeletal muscle from 10 patients undergoing major vascular surgery (Flear, Pickering, and McNeill, 1969b). Three biopsies of rectus abdominis were taken from each patient, one at the beginning and two at the end of the operation. One of these was taken from a portion of muscle that had been under a retractor for much of the operation (traumatized muscle), and one from an area of the same muscle that had not been exposed or handled (non-traumatized muscle). Ten slices were cut from each biopsy from each patient. Each slice was individually analysed for $\mathrm{Na}, \mathrm{K}$, $\mathrm{Cl}$, water, and fat. In all patients the rectus abdominis gained water, $\mathrm{Na}$, and $\mathrm{Cl}$ and lost $\mathrm{K}$ during operation. Similar changes have been noted after injury in muscle from animals (Fuhrman, 1960).

Our detailed findings could only be explained as resulting from cellular changes-imbalances in exchanges of water and electrolytes leading to net gains of $\mathrm{Na}$ and $\mathrm{Cl}$ and water and loss of $\mathrm{K}$, together with the escape of some previously nondiffusible solutes from cells.

Interpretation of our findings was based on a detailed individual evaluation of the differences in composition noted between samples from all the biopsies in each patient. From this we deduced whether or not the differences reflect varying proportions of cell and extracellular phases (solids as well as fluid) in each sample. Where differences do not arise in this way, but reflect differences in average composition of cells in slices, we consider it reasonable to presume that the difference in cell and tissue composition reflects the varying impact throughout the tissue sampled (and in this instance also between tissue sampled at the beginning and end of operations) of the major cellular changes caused by trauma. What these are may be revealed by additional scrutiny of the data. Certain patterns in the relationships between sample contents of water, $\mathrm{Na}, \mathrm{K}$, and $\mathrm{Cl}$ have been carefully defined corresponding to particular cellular changes. These are based on the detailed consequences of specified changes in cell composition which are predicted with the aid of the equations set out in the Appendix. ${ }^{1}$ Data are therefore examined to see which of these patterns is displayed. It is necessary to adopt this approach because unless a balanced state obtains across cell membranes the volume of extracellular fluid in pieces of skeletal muscle cannot be calculated ${ }^{2}$ so that it is not possible to partition total content into cellular and extracellular contributions. In a changing state with cells gaining $\mathrm{Na}$ the volume of extracellular fluid calculated for a sample of given composition depends upon the permeability assumed (Appendix). We were, however, able to conclude from our appraisal of patterns displayed that (1) a balanced state had not been reattained at the end of operation as cells were still gaining $\mathrm{Na}$; (2) on average skeletal muscle showed neither net gain nor loss of extracellular fluid. We were, therefore, able to say what the average volume of extracellular fluid was at the end of operation, since a reasonable estimate could be made of its average value in samples taken at the beginning of the operation. As a result, we were able to deduce that permeability of cell membranes increased during operation, and that the extent of this increase was more marked in the area of muscle that had been damaged during the operation (Fig. 5).

Further investigations will be necessary to establish for how long after operations cells continue to gain $\mathrm{Na}$ and lose $\mathrm{K}$. We also need to

\footnotetext{
${ }^{1}$ The derivation of some of these patterns has been presented and discussed elsewhere (Flear, 1969; Flear et al, 1969b).

${ }^{2}$ The simple calculation of extracellular fluid used by Graham, Lamb, and Linton (1967) is unreliable. It is necessary to assume a value for the resting membrane potential; Graham suggests $-85 \mathrm{mV}$. It can, for instance, be shown that the membrane potential will be very much less than $85 \mathrm{mV}$ during a period of continuing net gain of $\mathrm{Na}$ provoked or accompanied by increase in cell membrane permeability. Moreover the membrane potential has been found at times to be very low after a period of net gain of $\mathrm{Na}$ by cells (in vitro) when a balanced state may be presumed to be re-established (Cross, Keynes, and Rybova, 1965). Finally, calculations from our own data suggest that membrane potentials vary substantially in alimentary disease (Table III). They suggest, too, that there is a marked fall in potential during major operations. Calculations from data in reference (Flear et al, 1969b) indicate an average fall of $50 \mathrm{mV}$.
} 


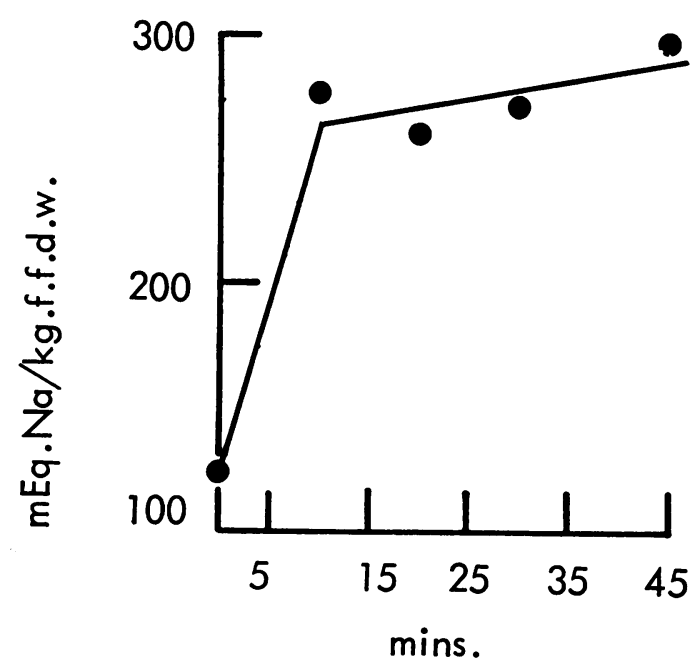

Fig. 6 Sodium content of bundles of fibres dissected at the times indicated from a biopsy of rectus abdominis immersed in an oxygenated saline at $22^{\circ} \mathrm{C}$ (for composition see unpublished data of Greener and Flear). Each point is the mean of four or five bundles.

establish whether skeletal muscle in general, ie, from parts of the body remote from the area of operation, show these same changes.

Swedish investigators report loss of $3 \% \mathrm{~K}$ from adductor muscle in the thigh of dogs shocked by blood loss (Hagberg, Haljamäe, and Röckert, 1968). This compares with an average loss of $3.5 \% \mathrm{~K}$ in our patients (Flear et al, 1969). The interval between taking control and postshock samples was two and a quarter hours, a time which is very similar to the average duration of our operations. They suggest that loss of $\mathrm{K}$ actually is more than this but that most of the lost $\mathrm{K}$ stays in the interstitial fluid and so is analysed (Hagberg et al, 1968). They find that single muscle fibres contain 10 to $50 \%$ less $\mathrm{K}$ after shock than before bleeding, and that bundles of fibres contain from 0 to $35 \%$ less $\mathrm{K}$ after shock (Hagberg, Haljamäe, and Röckert, 1967). Individual fibres and bundles alike were dissected with the biopsy immersed in Ringer saline at $20^{\circ} \mathrm{C}$ which had been oxygenated for 10 minutes with $95 \% \mathrm{O}_{2}, 5 \% \mathrm{CO}_{2}$ (Haljamäe, 1967). The Swedish investigators consider that this greater loss of $\mathbf{K}$ resulted from washing away $\mathrm{K}$ trapped in interstitial fluid. Dr Greener and $I$, however, find that bundles of human skeletal muscle fibres dissected in similar Ringer solution (at $22^{\circ} \mathrm{C}$ ) and gassed for one hour rapidly gain $\mathrm{Na}$ and water and lose $\mathrm{K}$ (Fig. 6). Their dissections took from five to $\mathbf{4 0}$ minutes. Our biopsies were taken at the beginning of operations, when there could be no question of significant blood loss or shock. We believe that the greater loss of $\mathrm{K}$ found in bundles and fibres from biopsies taken after shock, compared wixth bundles taken similarly from pre-shock biopsies, reflects an increase in cell membrane permeabi itty brought about by shock. Consequently $\mathrm{Na}$ engers more rapidly into post-shock fibres and loss of K will be more marked.

EVIDENCE FROM RELATIONSHIP BETWEE PLASMA OSMOLALITY AND LEVEL OF SODIUM

It was pointed out earlier that when a sufficient mass of tissue cells gain $\mathrm{Na}$ and chloride and at the same time some previously non-diffus olle solutes escape from cells the level of $\mathrm{Na}$ throughout extracellular fluid will fall without a falBin osmolality. Dr Singh and I have found that this is in fact what happens when shock is experimentally induced in dogs by blood loss and afocer surgery in man.

We first defined the relationship between osmolality and the plasma level of $\mathrm{Na}$ when change in both is brought about by dilutiron (Singh and Flear, 1968). Since levels of urea snd glucose can vary substantially in patients, osmolality was corrected by subtracting ?the osmotic contribution made by each of these substances. Osmolality and the level of $\mathrm{Na}$ wire measured in plasma (also urea, glucose, and water) before and after diluting it in vitro 8 by adding varying amounts of $5 \%$ dextrose. Simitar dilution studies were made by infusing $\$ \%$ dextrose intravenously and taking samplesoo blood from a vein some 3 to 6 inches proximal to the point of insertion of the drip needles. The 


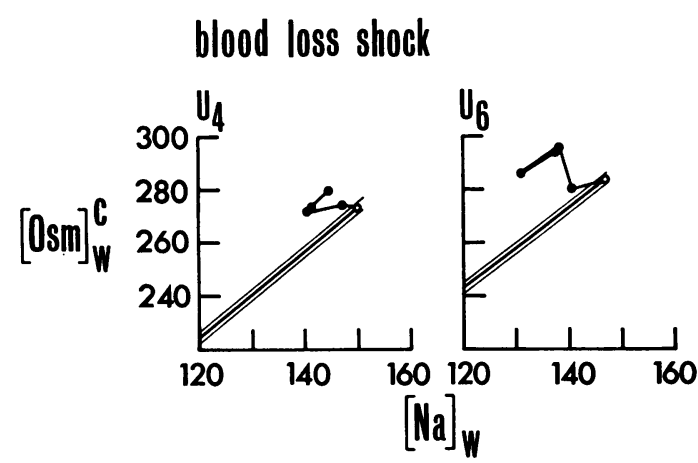

Fig. 8 Relationship between plasma levels of $\mathrm{Na}$ (m-equiv/kg plasma water: $[\mathrm{Na}]_{w}$ ) and osmolality corrected for urea and glucose ( $\mathrm{mOsm} / \mathrm{kg}$ plasma water: $[\mathrm{Osm}]_{w}{ }^{c}$ ) before (open circles) and during the development of blood loss shock in two dogs. The relationship caused by dilution is projected from the pre-shock values. The $95 \%$ confidence limits within which observations should be, if the fall in $\mathrm{Na}$ is caused by dilution, are also indicated (unpublished data, Singh and Flear).

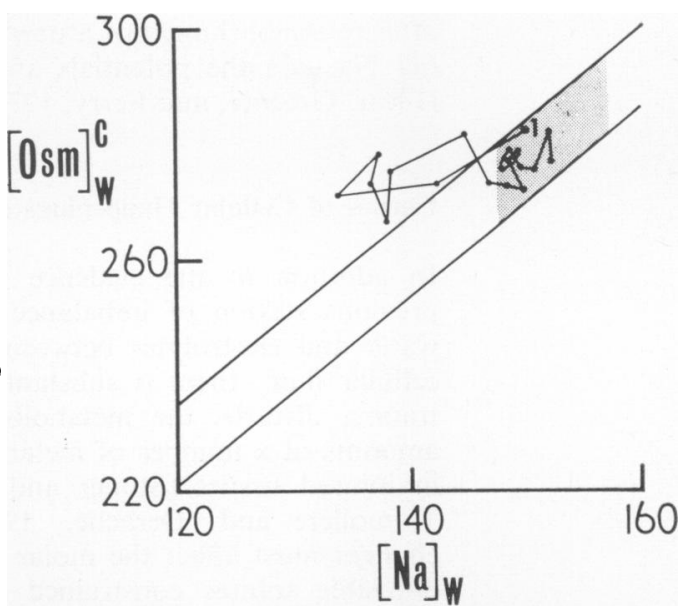

Fig. 9 Plasma levels of $\mathrm{Na}$ and osmolality (see Fig. 8) before surgery and at intervals thereafter for three weeks. The band is derived by fitting the average slope of dilution to the outermost values observed in a group of 50 healthy subjects (Singh and Flear, unpublished data).

rate of infusion was varied. Close agreement was noted between findings with both methods, and between the relationship found in different subjects. Figure 7 shows the relationship noted when plasma from one subject was diluted in vitro.

Observations were then made in 12 dogs before and while inducing shock by bleeding (Singh and Flear, 1969). Systolic blood pressure was dropped in all cases to $40 \mathrm{~mm} \mathrm{Hg}$ or less and held at that level for one or more hours. Total amounts of blood removed ranged from 1.8 to 2.8 litres. Findings were essentially the same in all dogs: the plasma $\mathrm{Na}$ level fell without a comparable fall in osmolality. Figure 8 shows data from two dogs. The oblique line depicts the relationship between $\mathrm{Na}$ and osmolality when change in both is brought about by dilution. This $r$ lationship was determined in all instances on blood taken before shock was induced. Figure 9 presents similar findings from a patient before, during, and after colectomy. We have similar findings after surgery in many other patients. Neither in experimental shock nor after surgery can the lack of a comparable fall in osmolality be explained by the rise in $\mathrm{K}$ level commonly seen.

These findings clearly demonstrate that hyponatraemia in shock is largely provoked by imbalance across cell membranes. This factor is of major importance also in the onset of hyponatraemia after surgery. Here, dilution also contributes to its onset and at times may be the overriding factor. This was Wynn's experience (Wynn and Robb, 1954; Wynn and Houghton, 1957). Most of his patients had received very generous transfusions of $5 \%$ dextrose, to the hazards of which he directed attention. Plasma $\mathrm{K}$ levels fell in his patients.

\section{OTHER EVIDENCE}

A final piece of evidence that trauma provokes cellular gain of $\mathrm{Na}$ is afforded by the observations that resting membrane potentials of skeletal muscle fibres, measured in situ, fall during the onset of shock induced in rats by bleeding (Shires and Carrico, 1966). More recently Shires and his colleagues also found that in man too membrane potentials (measurements in situ) were low when patients were admitted in traumatic shock, and that with recovery the potentials rose (Shires, 1969).

We have confirmed in vitro that while human skeletal muscle cells are accumulating $\mathrm{Na}$, their membrane potential falls (Table III), and that

\begin{tabular}{lllll}
\hline Controls & $\begin{array}{l}\text { Peptic } \\
\text { Ulcer } \\
\text { (3) }\end{array}$ & $\begin{array}{l}\text { Regional } \\
\text { Enteritis }\end{array}$ & $\begin{array}{l}\text { Ulcerative } \\
\text { Colitis } \\
(12)\end{array}$ & (14) \\
\hline
\end{tabular}

Maximum variation

(mV) within one

muscle in a given

$\begin{array}{lllll}\text { subject } & 10 & 23 & 19 & 36\end{array}$

Highest and lowest

potentials $(\mathrm{m} / \mathrm{V})$

noted in each group $87-99 \quad 60-100 \quad 81-104 \quad 80-124$

Table III Variation in calculated membrane potentials (rectus abdominis) in controls and in patients with alimentary disease ${ }^{1}$

${ }^{1}$ Unpublished data of Flear, Florence, and Williams calculated from tissue contents of $\mathrm{K}, \mathrm{Cl}$, water; and concentrations $\mathrm{K}$ and $\mathrm{Cl}$ in extracellular water. Equation 8 in the appendix was used. Biopsies were all taken at the beginning of operations.

The potential calculated for each sample of tissue is the average for all fibres in the sample. These potentials will therefore show less variation than would be apparent from actual measurements on individual fibres due to the smoothing effect of averaging.

From 10 to 30 observations were made in each individual. 
after re-establishment of a new balanced state of net $\mathrm{Na}$ gain the potentials are also subnormal (Flear, Greener, and Ferry, 1970).

\section{Causes of Cellular Happenings after Trauma}

In addition to the evidence presented in the previous section of imbalance in exchanges of water and electrolytes between cells and extracellular fluid, there is substantial evidence that trauma disturbs the metabolism of cells. The amounts of a number of metabolites are altered in injured tissues (Stoner and Threlfall, 1960; Trémolière and Derache, 1960), and these changes must affect the molar quantity of nondiffusible solutes constrained within cells, the balance of charges on them, and consequently also the amounts of water and cations in cells. Probably all cellular events after trauma are partly caused by hypoxia and tissue underperfusion. Ischaemia of skeletal muscle, heart, (Lamprecht, 1967) is known to affect levels of ATP etc in tissues in animals and man. Whilst the shift to anaerobic metabolism in the myocardium following the sudden arrest of the coronary blood flow occurs in an oscillatory fashion (Wollenberger and Krause, 1968), it is likely to be accompanied by similar fluctuations in the amounts of various compounds within cells. Moreover, ischaemia of the lower limbs in animals provokes breakdown of glycogen in the liver and skeletal muscle elsewhere in the body. Anoxaemia induced by breathing nitrogen provokes a considerable upset of metabolism, as judged by the resultant rapid increase in osmolality of body fluids (Battaglia, Meschia, Helligers, and Baron, 1958). It has also been shown to increase the permeability of cells in situ and in vitro, and in vitro to inhibit extrusion of $\mathrm{Na}$ and to provoke breakdown of labile compounds. Elsewhere I have presented evidence from patients that skeletal muscle cells in ischaemic limbs show changes similar to those induced by anoxia in vitro (Flear, 1969: see Fig. 9). More recently in nine patients operated upon by Mr Donald Ross, Dr Singh and I noted striking gains of $\mathrm{Na}$ and $\mathrm{Cl}$ by ventricular heart muscle cells, losses of $\mathrm{K}$, and variation in the amounts of non-diffusible anions following peroperative anoxic arrest of the heart (Singh, Flear, and Ross, 1969). Losses of $K$, for instance, ranged from 35 to $168 \mathrm{~m}$-equiv per kilogram fat-free dry weight, an average loss of $30 \%$.

Other factors may also provoke imbalance in the exchange of water and electrolytes across cell membranes. My colleagues and I have evidence that $E$. coli endotoxin provokes a considerable increase in the permeability of a substantial mass of body cells. Figure 10 presents observations to this effect on the plasma levels of $\mathrm{Na}$ and osmolality in two dogs before and after they had been shocked by infusing a killed suspension of $E$. coli.

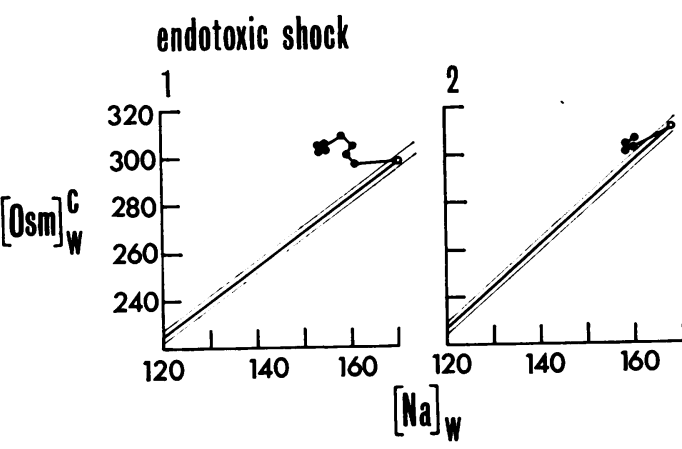

Fig. 10 Plasma levels of Na and osmolality (see Fig. 8) before and after inducing shock in two dogs by injecting intravenously aliquots of a suspension of killed $\mathrm{E}$. coli in water.

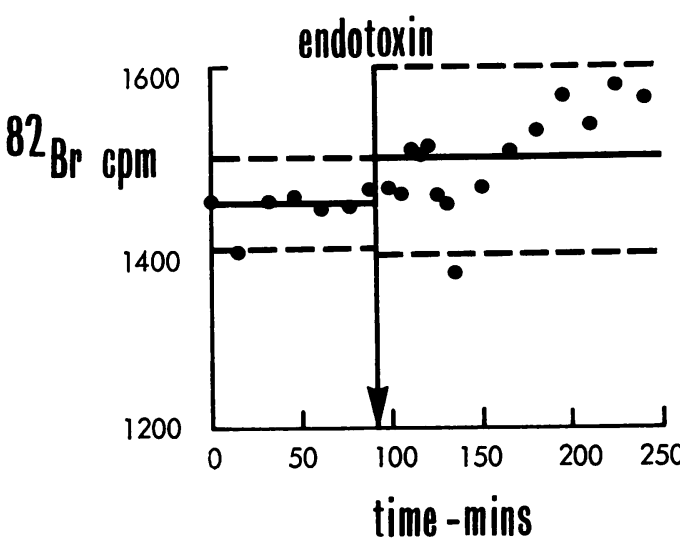

Fig. 11 Counts of ${ }^{82} \mathrm{Br}$ in plasma before and after injecting sufficient $\mathrm{E}$. coli endotoxin (strain CA 38) into a dog to lower systolic blood pressure to $50 \mathrm{~mm} \mathrm{Hg}$.

Other evidence to the same effect was obtainech on 16 dogs, splenectomized 10 days before being given $E$. coli endotoxin intravenously (Batey을. Flear, and McNeill, 1970). These dogs were given ${ }^{82} \mathrm{Br}$ by injection some 12 to 15 hours previously Over a control period the concentration of ${ }^{82} \mathrm{~B} P$ in plasma was constant. During shock, the mearw ${ }^{82} \mathrm{Br}$ count per millilitre of plasma in all but one of the dogs rose above control levels (Fig. 11) We conclude that this is due to shrinkage of extracellular fluid around the quantity of ${ }^{82} \mathbf{B r}$ that it contains. This effect would be expected if endotoxins caused disequilibration in the parti市 tion of water and electrolytes across cell mem $\frac{\text { Pे }}{\mathbb{N}}$ branes. Moreover, after giving endotoxin the variability between plasma counts increasee which, we believe, supports our inference. Celle will gain some ${ }^{82} \mathrm{Br}$ along with $\mathrm{Na}$ and $\mathrm{Cl}$, an it is therefore not possible to quantitate the shrinkage in extracellular fluid by this technique. However, the haematocrit was seen to rise after 
injecting endotoxin, affording evidence that plasma volume shrinks.

$E$. coli endotoxin has also been observed to increase the permeability of skeletal muscle to $\mathrm{Na}$. Uptake of $\mathrm{Na}$ by frog sartorius muscle (at $0^{\circ} \mathrm{C}$ ) is faster from plasma taken from dogs during endotoxic shock than from plasma taken before injecting endotoxin (Greener, Singh, and Flear, 1969). When the findings were presented to the Surgical Research Society they were merely suggestive. They have since been expanded and shown to be significant. Evidence has also been obtained that $E$. coli endotoxin similarly increases the uptake of $\mathrm{Na}$ in vitro by human skeletal muscle (at $0^{\circ} \mathrm{C}$ ) from the person's own plasma, and also that it provokes striking changes in the molar quantity of non-diffusible organic solutes constrained within cells. It is of related interest that, according to Kovách and Fonyo (1960), Boda found that serum and cerebrospinal fluid in infants in toxicosis inhibits glucose uptake by rat diaphragm.

Finally, Graber and I (ms. only) concluded from detailed balance studies that the abrupt clinical onset of endotoxic shock in a young woman was associated with cell gain of $\mathrm{Na}$ and $\mathrm{Cl}$ and loss of $\mathrm{K}$. These changes continued until the toxic period, as well as the period of circulatory instability, had been successfully negotiated. During recovery they reversed. It was also noted that the marked swings in plasma $\mathrm{Na}$ could not be explained as simple consequences of gains or losses of water and cations (Table IV).

\begin{tabular}{lll}
\hline Phase (No.) & & $\begin{array}{l}\text { Extracellular Water } \\
\text { (m-equiv/days) }\end{array}$ \\
\hline Circulatory collapse & $(1)$ & 205 \\
Toxic & $(2)$ & 44 \\
Recovary & $(3)$ & 18 \\
& $(4)$ & 6 \\
& $(5)$ & 4 \\
\hline
\end{tabular}

Table IV Discrepancy between observed and expected balance of $\mathrm{Na}+\mathrm{K}$ from daily water balance ${ }^{1}$ and the concentration (m-equiv $(\mathrm{Na}+\mathrm{K}) / 6$ ) extracellular water in one patient

${ }^{1}$ Graber and Flear (1970).

The possibility that other factors associated with trauma and its sequelae may provoke imbalance in exchanges across cell membranes should not be ignored. For instance, catecholamines increase and there is evidence that they affect membranes and $\mathrm{Na}$ pumps.

\section{Wider Relevance of Cellular Events and of Investigations of Trauma}

I would conclude by affirming my belief that the changes in water and electrolytes, and in nitrogen metabolism also, that we see after trauma are the result of perturbations or sustained dislocations of cell metabolism and the permeability of their

membranes. I suggest that increased production and release of adrenal steroids, and possibly $\mathrm{ADH}$, are consequences rather than causes of disturbances in water and electrolytes. If this is so, then I believe that it raises questions of therapeutic importance, and also that researches into events which follow trauma perhaps assume added significance.

QUESTIONS OF THERAPEUTIC RELEVANCE

Perhaps the most obvious of these concerns what can be done to lessen or prevent, and also to reverse, changes in membrane permeability, active transport of $\mathrm{Na}$, in the molar quantity of non-diffusible solutes, including anions, or to lessen their consequences for water and electrolyte partition.

As we have seen, the consequences of cellular events vary. Abrupt swelling of cells causes an equally rapid shrinkage of extracellular fluid, and it seems probable that these events could be the mechanism underlying the abrupt onset of shock which may develop in septic and toxic situations. Shrinkage of plasma as a result of shift of fluid into the interstitial fluid, provoked by the concentrating effect on interstitial fluid protein levels of cell swelling, is unlikely to be seriously opposed by an increase in tissue pressure. Observations on skin (Guyton and Coleman, 1967), have shown that after an initial increase in pressure tissue becomes strikingly pliant so that marked swelling is tolerated with little or no further rise in pressure. In the case of skeletal muscle, cell swelling will produce a fall in resting membrane potential, whence loss of muscle tone, so that tissue pressure may even fall.

The use of hypertonic saline has been suggested as a means of lessening cellular swelling (Brooks, Williams, Manley, and Whiteman, 1963); efficacy is lessened or even cancelled by the greater influx of $\mathrm{Na}$ into cells caused by a raised level of $\mathrm{Na}$ in extracellular fluid. Probably salt-free albumin would be the most appropriate infusion fluid. It would lessen plasma volume shrinkage and not increase the influx of sodium.

It seems likely that tissue underperfusion in shock will promote a vicious spiral of cell swelling, shrinkage of plasma volume, or further underperfusion. I would suggest that the reduced blood flow to skeletal muscle seen in shock is thus of greater significance than has been thought hitherto since it may provoke such a spiral.

Accumulation of $\mathrm{Na}$ in heart muscle cells is of special significance. It causes a fall in resting membrane potential. A slight fall increases the excitability of fibres, and if this happens unevenly throughout the myocardium it may cause arrhythmia. Greater fall causes a fibre to become inexcitable, and, if a sufficient proportion of the hearts fibres are so affected, cardiac output must fall. I believe that these events underly complications not infrequently seen after heart surgery, 
particularly the complication associated with anoxic arrest of the heart.

Hinton and Allison (1969) report the successful use of infusions of insulin and glucose after trauma and suggest that insulin is the active factor promoting extrusion of sodium from cells. Kernan (1962) presented evidence for such an action by insulin, and it would seem worth assessing its value after heart surgery. It has of course been used for this purpose after myocardial infarction (Sodi-Pallares, Bisteni, Medrano, Micheli, Ponce de Léon, Calva, Fishleder, Testelli, and Miller, 1966; Sodi-Pallares, Ponce de Léon, Bisteni, and Medrano, 1969), in refractory congestive heart failure (Brenner, 1960), and in terminal carcinoma associated with hyponatraemia (Neufeld, 1962).

My interpretation of events after trauma raises the question of what should be our attitude towards hyponatraemia and hyperkalaemia. If these disturbances arise as outlined serious consideration should be paid to the possibility that they are more appropriate levels than 'normal' ones would be in the prevailing circumstances. If this is so attempts should not be made to alter them directly. Elsewhere, discussing events in congestive heart failure, it was pointed out that both low $\mathrm{Na}$ and high $\mathrm{K}$ levels facilitate transport of $\mathrm{Na}$ from cells (Flear, 1969).

WIDER SIGNIFICANCE OF RESEARCH INTO EVENTS AFTER TRAUMA

There is an increasing awareness of the relevance of changes in cell membranes and $\mathrm{Na}$ pumps, in many situations. Some hormones (Christensen, 1962) and drugs (Burgen, 1967) act at this level, and disturbances in active transport of $\mathrm{Na}$ from erythrocytes have been reported in uraemia (Weth, Sachs, and McManus, 1964; Welt, Smith, Dum, Czerwinski, Proctor, Cole, Balfe, and Gitelmâg, 1967; Smith, Welt, and Czerwinski, 1967), malaria (Dunn, 1968), and thyrotoxicosis (Smith and Samuel, 1970). Elsewhere I have discuss $\overrightarrow{\text { d d }}$ evidence for alterations in permeability, etc, $\frac{\text { In }}{\delta}$ progressive heart failure (Flear, 1966, 1969).

Insight gained into disturbances at this le after trauma will thus be of wide interest. Molover, trauma offers the advantage of being ${ }_{\mathrm{a}}$ disturbance with a discrete and known abrupt onset in time. It has the feature too of arising $\vec{\phi}$. both the previously healthy and the chronicalty ill: in both its consequences may be reversibfe. It does of course pose the problem of research the midst of intense activity directed at the survival of the patient.

Researches have been supported by the Royâl Society, the Scientific and Research Sub-Co型mittee of the Royal Victoria Infirmary, Newcast $\vec{e}$, and Muscular Dystrophy Group of the United Kingdom, The Wellcome Foundation, and Geigy Pharmaceuticals.

My thanks are due to Miss Barbara James and others of the University Department of Photography for help with the figures. I should also like to record my appreciation of the many he/8ful discussions with many colleagues, in po ticular, George Graber, Ian McNeill, Chander Mohan Singh, and John Greener.

Dr Harry Richardson (Department of Micrêेbiology, University of Newcastle) kindly supplied the suspension of killed $E$. coli.

\section{Appendix}

\section{Prediction of the effect of variation in cellular content of sodium upon the amount of water and potassium in cells}

\section{During a Balanced State}

This is a state of zero net flux of water and ions, and here the partition is in accord with the following equilibria.

Electrical neutrality

$$
[\mathrm{K}]_{\mathrm{i}}+[\mathrm{Na}]_{\mathrm{i}}=[\mathrm{Cl}]_{\mathrm{i}}-\frac{\mathrm{zA}}{\mathrm{V}} \quad \ldots 1
$$

for osmotic balance across the cell membrane

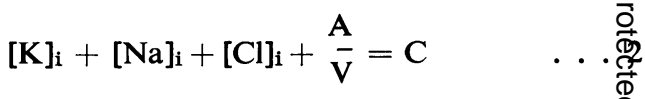

for a Donnan equilibrium

$[\mathrm{K}]_{\mathbf{i}}[\mathrm{Cl}]_{\mathbf{i}}=[\mathrm{K}]_{\mathbf{0}}[\mathrm{Cl}]_{0}$ $\frac{\frac{0}{0}}{\frac{0}{0}}$ where []$_{i}$ denote concentrations in cell wate; []$_{0}$ in extracellular water. 
$\mathrm{V}$ represents the volume of cell water, and is taken as unity in the initial resting circumstance.

A represents mols of non-diffusible material in $\mathrm{V}$.

zA represents the sum of the electrical charges on $\mathrm{A}$, represented as milliequivalents of anions ( $\mathrm{z}$ is average valence of $\mathrm{A}$ ).

C represents total external concentration less that due to freely diffusible substances, such as urea, present in equal concentration on either side of cell membranes. Equations 1, 2, and 3 may be combined to give an equation which can be used to predict the outcome of changes in one or more of the terms in equations 1,2 , and 3.

$$
\begin{gathered}
\mathrm{V}^{2}\left\{\mathrm{C}^{2}-4[\mathrm{~K}]_{0}[\mathrm{Cl}]_{0}+2[\mathrm{Na}]_{\mathrm{i}} \mathrm{C}\right\}+ \\
\mathrm{V}\left\{2[\mathrm{Na}]_{\mathrm{i}} \mathrm{A}(1-\mathrm{z})-2 \mathrm{CA}\right\}+ \\
\mathrm{A}^{2}\left(1-\mathrm{z}^{2}\right)=0
\end{gathered}
$$

Equation 4 can be used with equation 5 below, to predict the effects of cell content and concentration of $\mathrm{Na}, \mathrm{K}$, chloride on $\mathrm{A}$ and $\mathrm{zA}$ and on cell content of water of (1) gain of sodium by cells, (2) change in A, and (3) change in $\mathrm{zA}$ either singly or jointly (Flear, 1969). The procedure is to substitute the postulated new value of $[\mathrm{Na}]_{i}$ etc in equation 4 and solve for $\mathrm{V}$.

The value $[\mathrm{Cl}]_{i}$ is then derived from the equation

$$
2[\mathrm{Cl}]_{\mathrm{i}}=\mathrm{C}-(\mathrm{A} / \mathrm{V})(1-\mathrm{z})
$$

obtained by subtracting equation 1 from equation 2. $[\mathrm{K}]_{\mathrm{i}}$ is then obtained using equation $3 ; \mathrm{A} / \mathrm{V}$ from equation 2 , etc.

\section{During a Changing State of Net Na Gain by Cells}

Here equations 1 and 2 obtain, but as the potential across cell membranes is a diffusion potential equation 3 is invalid. Instead we may write

$$
\begin{aligned}
& {[\mathrm{K}]_{\mathrm{i}}(\mathrm{Cl}]_{\mathrm{i}}=[\mathrm{K}]_{0}[\mathrm{Cl}]_{0}+\mathrm{b}[\mathrm{Na}]_{0}[\mathrm{Cl}]_{0}-} \\
& \mathrm{b}[\mathrm{Na}]_{\mathrm{i}}[\mathrm{Cl}]_{\mathrm{i}} \ldots 6
\end{aligned}
$$

where $b$ is the ratio of the permeability factors for $\mathrm{K}$ and $\mathrm{Na}\left(\mathrm{P}_{\mathrm{K}} / \mathrm{P}_{\mathrm{Na}}\right)$.

Combining equations 1,2 , and 6 one can obtain

$$
\begin{aligned}
& \mathrm{V}^{2}\left\{\mathrm{C}^{2}-2(1-\mathrm{b})[\mathrm{Na}]_{\mathrm{i}} \mathrm{C}-4\left([\mathrm{~K}]_{0}[\mathrm{Cl}]_{0}+\mathrm{b}\right.\right. \\
& \left.\left.[\mathrm{Na}]_{0}[\mathrm{Cl}]_{0}\right)\right\} \\
& \left.+2 \mathrm{~V}\{(1-\mathrm{b})] \mathrm{Na}]_{\mathrm{i}} \mathrm{A}-(1-\mathrm{b})[\mathrm{Na}]_{\mathrm{i}} \mathrm{ZA}-\mathrm{CA}\right\} \\
& +\mathrm{A}^{2}\left(1-(\mathrm{z})^{2}\right)=0
\end{aligned}
$$

which is analogous to equation 4 .

It has been used to predict the consequences of imbalance between influx and efflux of sodium, first assuming no change in the permeability of cell membranes $(b=0.01)$ and subsequently assuming the following values for $b=0 \cdot 1,0 \cdot 5$, and 1.0 , that is, assuming that cell membranes become abnormally permeable.

Separate calculations were made for the three situations where the rate of Na pumping is nearly equal to the passive influx that would obtain when $[\mathrm{Na}]_{0}=140 \mathrm{~m}$-equiv $/ \mathrm{l}$ and $[\mathrm{Na}]_{i}$ was 50 , 80 , and $120 \mathrm{~m}$-equiv/l. The procedure was as indicated in previous sections. The assumed initial composition of cellular and extracellular fluids was

$[\mathrm{Na}]_{\mathrm{i}}=10 ;[\mathrm{K}]_{\mathrm{i}} \quad[\mathrm{Cl}]_{\mathrm{i}}=500 ;[\mathrm{K}]_{\mathrm{i}}=160$; $\mathrm{A}=117 ; \mathrm{zA}=-167 ;[\mathrm{Na}]_{0}=140 ;[\mathrm{K}]_{0}=$ $5 ;[\mathrm{Cl}]_{0}=100 ; \mathrm{C}=290$.

The composition of extracellular fluid was presumed to remain constant.

The effects were then calculated of abrupt swelling of cells, of the order calculated to arise in the above situations, on the volume of extracellular fluid, and on body $\mathrm{K}$, in a $70 \mathrm{~kg}$ adult whose $\Sigma \mathrm{H}_{2} \mathrm{O}=60 \%$ body weight, $\Sigma$ intracellular fluid $=301 \Sigma$ extracellular fluid $=121$.

These effects were calculated assuming (1) $10 \%$, (2) $20 \%$, and (3) $30 \%$ of the body's cell mass was implicated. Skeletal muscle was presumed to comprise $50 \%$ of the body cell mass. Pertinent results are presented in Figures 3 and 4.

\section{Calculation of Extracellular Fluid Volume from Tissue Contents of $\mathrm{Na}, \mathrm{K}, \mathrm{Cl}$, and Water}

Conway (1957) first showed that, providing a balanced state obtained, the volume of extracellular fluid could be calculated from tissue contents of $\mathrm{K}, \mathrm{Cl}$, and water, plus the concentrations of $\mathrm{K}$ and $\mathrm{Cl}$ in extracellular water using the equation

$$
\begin{aligned}
& \mathrm{Vo}=\left(\mathrm{K}_{\mathrm{t}} \mathrm{Cl}_{\mathrm{t}}-[\mathrm{K}]_{0}[\mathrm{Cl}]_{0} \mathrm{~V}_{\mathrm{t}}{ }^{2}\right) / \\
& \left(\mathrm{K}_{\mathrm{t}}[\mathrm{Cl}]_{0}+\mathrm{Cl}_{\mathrm{t}}[\mathrm{K}]_{0}-2 \mathrm{~V}_{\mathrm{t}}[\mathrm{K}]_{0}[\mathrm{Cl}]_{0}\right) \ldots 8
\end{aligned}
$$

where $\mathrm{Vo}=$ kilograms of extracellular fluid per kilogram fat-free dry weight of tissue.

$\mathrm{K}_{\mathrm{t}}$ and $\mathrm{Cl}_{\mathrm{t}}$ denote tissue contents in milliequivalents per kilogram fat-free dry weight of tissue

$\mathrm{V}_{\mathrm{t}}=$ kilograms of tissue water per kilogram fat-free dry weight.

Other symbols are defined above. (See reference for a discussion of the derivation of the formula used. It is based on equation 3 above.)

In similar fashion it can be shown that during a changing state of sodium gain, the volume of extracellular fluid can be calculated from tissue contents of $\mathrm{Na}, \mathrm{K}, \mathrm{Cl}$, and water, and the concentration of these ions in extracellular water:

$$
\begin{aligned}
& \mathrm{V}_{0}=\left\{\left(\mathrm{K}_{\mathrm{t}} \mathrm{Cl}-[\mathrm{K}]_{0}[\mathrm{Cl}]_{0} \mathrm{~V}_{\mathrm{t}}{ }^{2}\right)+\right. \\
& \left.\mathrm{b}\left(\mathrm{Na}_{\mathrm{t}} \mathrm{Cl}_{\mathrm{t}}-[\mathrm{Na}]_{0} \mathrm{Cl}_{0} \mathrm{~V}_{\mathrm{t}}{ }^{2}\right)\right\} / \\
& \left\{\left(\mathrm{K}_{\mathrm{t}}[\mathrm{Cl}]_{0}+\mathrm{Cl}_{\mathrm{t}}[\mathrm{K}]_{0}-2 \mathrm{~V}_{\mathrm{t}}[\mathrm{K}]_{0}[\mathrm{Cl}]_{0}\right)+\right. \\
& \mathrm{b}\left(\mathrm{Na}_{\mathrm{t}}[\mathrm{Cl}]_{0}+\mathrm{Cl}_{\mathrm{t}}[\mathrm{Na}]_{0}-2 \mathrm{~V}_{\mathrm{t}}[\mathrm{Na}]_{0}[\mathrm{Cl}]_{0}\right\}
\end{aligned}
$$

$\mathrm{Na}_{\mathrm{t}}=$ milliequivalents $\mathrm{Na}$ per kilogram fatfree dry weight of tissue. 
References

Adrian, R. H. (1960). Potassium chloride movement and the membrane potential of frog muscle. J. Physiol. (Lond.), 151, 154-185.

Aebi, H. (1952). Ueber die chemische und morphologische Natur der Stickstoffabgabe von Gewebsschnitten im Warburg-versuch. Biochim. biophys. Acta. (Amst.), 9, 443-456.

Aebi, H. (1953). Elektrolyte Akkumulierung und Osmoregulation in Gewebesschnitten. Helv. physiol. Acta, 11, 96-121.

Andres, R., Cader, G., Goldman, S. P., and Zierler, K. L. (1957). Net potassium movement between resting muscle and plasma in man in the basal state and during the night. $J$. clin. Invest., 36, 723-729.

Batey, N. R., Flear, C. T. G., and McNeill, I. F. (1970). The effect of $E$. coli endotoxin on extracellular fluid volume. Communication to the Surgical Research Society Meeting, Glasgow, January, 1970.

Battaglia, F. C., Meschia, G., Hellegers, A., and Barron, D. H. (1958). The effects of acute hypoxia on the osmotic pressure of the plasma. Quart. J. exp. Physiol., 43, 197-208.

Bernal, J. D. (1965). The structure of water and its biological implications, pp. 17-31. In The State and Movement of Water in Living Organisms. S.E.B. Symposium XIX 1965.

Boyle, P. J., and Conway, E. J. (1941). Potassium accumulation in muscle and associated changes. J. Physiol. (Lond.), 100, 1-63.

Brenner, O. (1960). The management of congestive heart failure. In Modern Trends in Cardiology, edited by E. Morgan Jones, p. 82. Butterworths, London.

Brooks, D. K., Williams, W. G., Manky, R. W., and Whiteman, P. (1963). Osmolar and electrolyte changes in haemorrhagic shock-hypertonic solutions in the prevention of tissue damage. Lancet, 1, 521-527.

Brown, F., and Stein, W. D. (1960). Balance of water, electrolytes, and nonelectrolytes. In Comparative Biochemistry, Vol. 2, edited by M. Florkin, and H. S. Mason, pp. 403-470. Academic Press, New York.

Burgen, A. S. V. (1967). The effect of drugs on membrane transport. Proc. roy. Soc. Med., 60, 329-334.

Christensen, H. N. (1948). The distribution of amino acids between cellular and extracellular fluids. Relation to growth. Bull. New Engl. med. Cent., 10, 108-111.

Christensen, H. N. (1962). Biological Transport. Benjamin, New York.

Conway, E. J. (1945). The physiological significance of inorganic levels in the internal medium of animals. Biol. Rev., 20, 56-72.

Conway, E. J. (1957). Nature and significance of concentration relations of potassium and sodium ions in skeletal muscle. Physiol. Rev., 37, 84-132.

Cross, S. B., Keynes, R. D., and Rybova, R. J. (1965). The coupling of sodium efflux and potassium influx in frog muscle. J. Physiol. (L.ond.), 181, 865-888.

Diamond, J. M., and Wright, E. M. (1969). Biological membranes: the physical basis of ions and nonelectrolyte selectivity. Ann. Rev. Physiol., 31, 582.646.

Dunn, M. J. (1968). Aberrations of red blood cell sodium transport during malarial infection. (Abstr.) Clin. Res., 16, 382.

Egdahl, R. H., Mack, E., and Herman, A. (1969). The effect of haemorrhage on adrenocortical perfusion and function. (Abstr.). Brit. J. Surg., 56, 703.

Flear, C. T. G., and Rajasingham, M. S. Unpublished observations.

Flear, C. T. G. (1966). Disturbance of volume and composition of body fluids in congestive heart failure. In Electrolytes and Cardiovascular Diseases, edited E. Bajasz, vol. 2, p. 357. Karger, Basel, New York.

Flear, C. T. G. (1969). Alterations in water and electrolyte dis. tribution in congestive heart failure and their significance. Ann. N.Y. Acad. Sci., 156, 421-444.

Flear, C. T. G. (1967). Significance of potassium and sodium masses in cardiac disease. In Compartments Pools and Spaces in Mediral Physiology, edited by P-E. E. Bergner, p. 53, and C. C. Lushbaugh (see pp. 53, and 123-138). U.S. Atomic Energy Commission Division of Technical Information, 1967.

Flear, C. T. G., and Clark, R. (1955). The influence of blood loss and blood transfusion upon changes in the metabolism of water, electrolytes, and nitrogen following civilian trauma. Clin. Sci., 14, 575-599.

Flear, C. T. G., Greener, J. S., and Ferry, C. B. (1970). Active transport of sodium from human skeletal muscle: an in vitro technique and findings. In 5th Symposium on Current Research in Muscular Dystrophy and Related Diseases. London.
Flear, C. T. G., McNeill, I. F., Greener, J. S., and Singh, C (1969a). Crystalloid administration in shock and surgieal trauma. (Letter.) Lancet, 2, 155.

Flear, C. T. G., Pickering, J., and McNeill I. F. (1969b). Obse円7ations on water and electrolyte changes in skeletal mussle during major surgery. J. Surg. Res., 9, 369-382.

Fuhrman, F. A. (1960). Electrolytes and glycogen in injured tissues. In The Biochemical Response to Injury, edited by H. B. Stoner and C. J. Threlfall, p. 5. Blackwell, Oxförd.

Graber, I. G., and Flear, C. T. G. (1970). Water electrolyte Fnd nitrogen balance studies in the successful management of a case of severe endotoxic shock in the puerperium, c. plicated by staphylococcal enteritis. (In manuscript.) $\bar{\omega}$

Graham, J. A., Lamb, J. F., and Linton, A. L. (1967). Measfrement of body water and intracellular electrolytes by mens of muscle biopsy. Lincet, 2, 1172-1176.

Greener, J., Singh, C. M., and Flear, C. T. G. (1969). Dobes plasma from shocked or uraemic dogs contain a faetor which increases permeability of skeletal muscle-cell meinbrane. (Abstr.) Brit. J. Surg., 56, 623.

Guyton, A. C., and Coleman, T. G. (1967). Long term regulation of the circulation: interrelationships with body volumes. In The Physical Bases of Circulatory Transport, edited by E. B. Reeve and A. C. Guyton, ch. II. Saundẹts, Philadelphia, London.

Haljamäe, H. (1967). Shock reactions in skeletal muscle. $\hat{W}_{\mathrm{A}}$ method for determining the potassium content of sifgle skeletal muscle cells. Acta chir. scand., 133, 259-363. -

Hagberg, S., Haljamäe, H., and Röckert, H. (1967). ShockFeactions in skeletal muscle, II. Intracellular potassium of skeletal muscle before and after induced haemorrhagic shock. Acta chir. scand., 133, 265-268.

Hagberg, S., Haljamäe, H., and Röckert, H. (1968). Shock reactions in skeletal muscle. III. The electrolyte conten⿳亠口冋 tissue fluid and blood plasma before and after indueted haemorrhagic shock. Ann. Surg., 168, 243-248.

Hinton, P., and Allison, S. P. (1969). Crystalloid administra שon in shock and surgical trauma. Lancet, 2, 594-595.

Jacobs, M. H. (1935). In Diffusion Process, 1967. Springer-Veridg, Berlin and New York. (Reprinted from Ergebnisse Jer Biologie Zwolfter Band, 1935.)

Kernan, R. P. (1962). The role of lactate in the active excretionof sodium by frog muscle. J. Physiol. (Lond.), 162, 129-\$7.

Kovách, A. G. B., and Fonyo, A. (1960). Metabolic response șto injury in cerebral tissue. In The Biochemical Respons Injury, edited by H. B. Stoner and C. J. Threfall, p. ha. Blackwell, Oxford.

Küsel, H., and Netter, H. (1952). Beweis der Conway-The grie $_{\text {ie }}$ über die Ionenverteilung im Muskel. Biochem. Z., 323, 39-52.

Lamprecht, W. (1967). Substrate and energy metabolism in hểrt failure. In an International Symposium on Coronery Circulation and Energetics of the Myocardium, Mitan, 1966 , p. 186. Karger, Basel, New York.

Landis, E. M., and Pappenheimer, J. R. (1963). Exchange of substances through the capillary walls. Ch. 29 in Handbogk of Physiology. Circulation Vol. 2. American Physiological Society.

Langer, G. A. (1968). Ion fluxes in cardiac excitation and ęontraction and their relation to myocardial contractifigy. Physiol. Rev.. 48, 708-757.

Leaf, A. (1956). On the mechanism of fluid exchange of tissthes in vitro. Biochem. J., 62, 241-248.

Ling, G. N., and Ochsenfeld, M. M. (1966). Studies on Pon accumulation in muscle cells. J. gen. Physiol., 49, 819-8

Lockwood, A. P. M. (1963). Animal Body Fluids and Their Regmation. Heinemann, London.

Lukowsky, G., and Netter, H. (1952). Zur Theorie der Kaliânschwelle an der Muskulatur. Biochem. Z., 323, 53-66.

McDowell, M. E., Wolf, A. V., and Steer, A. (1955). Osmøic volumes of distribution. Idiogenic changes in osmofc pressure associated with administration of hypertonic solutions. Amer. J. Physiol., 180, 545-558.

McNcill, I. F., and MacKenzie, A. Unpublished observation

Mond, R. (1955). Transport von K, Cl Wasser durch die Mus Eflfasermembran. Pflugers Arch. ges. Physiol., 261, 243-248.

Mullins, L. J. (1959). The penetration of some cations into muscte. J. gen. Physiol., 42, 817-829.

Mullins, L. J. (1960). An analysis of pore size in excitable menbranes. J. gen. Physiol., 43, Suppl. 1, 105-117.

Mullins, L. J., and Frumento, A. S. (1963). The concentrafon dependence of sodium efflux from muscle. J. gen. Phys 31 . 46, 629-654.

Mullins, L. J., and Awad, M. Z. (1965). The control of the membrane potential of muscle fibers by the sodium punp. J. gen. Physiol., 48, 761-775.

Netter, H. (1969). Theoretical Biochemistry, Oliver and Bord, Edinburgh. 
Neufeld, O. (1962). Insulin therapy in terminal cancer: a preliminary report. Amer. J. geriat. Soc., 10, 274-276.

Nunn, J. F. (1965). Influence of age and other factors on hypoxaemia in the postoperative period. Lancet, 2, 466-468.

Nunn, J. F., and Freeman J. (1964). Problems of oxygenation and oxygen transport during haemorrhage. Anaesthesia, 19, 206-216.

Olmstead, E. G. (1966). Mammalian Cell Water. Kimpton, London.

Post, R. L., and Jolly, P. C. (1957). The linkage of Na, K, and ammonium active transport across the human erythrocyte membrane. Biochim. biophys. Acta (Amst.), 25, 118-128.

Potts, W. T. W., and Parry, G. (1964). Osmotic and Ionic Regulation in Animals. Pergamon Press, Oxford.

Robinson, J. R. (1960). Body fluid dynamics. In Mineral Metabolism, vol. 1, pt A, edited by C. F. Comar and F. Bronner, p. 205-248. Academic Press, New York and London.

Robinson, J. R. (1965). Water regulation in mammalian cells. In The State and Movement of Water in Living Organisms, S.E.B. Symposium No. xix, pp. 237-258. C.U.P.

Ross, E. J. (1965). Aldosterone and its antagonists. Pharmacol. Ther., 6, 65-106.

Schoffeniels, E. (1967). Cellular .4spects of Membrane Permeability. Pergamon Press, Oxford.

Shires, T. (1969). Personal communication.

Shires, T., and Carrico, C. J. (1966). Current Status of the Shock Problem. Curr. Probl. Surg.

Singh, C. M. (1965). Effect of major surgery on blood volume and thiocyanate space. MS Thesis, Christian Medical College, Ludhiana Punjab, India.

Singh, C. M., and Flear, C. T. G. (1968). Why does the plasma sodium level fall after surgery? Brit. J. Surg., 55, 858 . (Abstr.)

Singh, C. M., and Flear, C. T. G. (1969). Experimental haemorrhagic and endotoxic shock in dogs; evidence for imbalance in exchanges of water and solutes across cell membranes. (Abstr.) Brit.J. Surg., 56, 703.

Singh, C. M., Flear, C. T. G., and Ross, D. (1969). Anoxic arrest during heart surgery, its effects on water and electrolyte contents of the human heart. 2nd Annual Meeting. International Study Group for Research in Cardiac Metabolism, Milan/Gargnano, Sept. 1969. (To be published in full in a separate volume of Rendiconti dell'Instituto Lombardo di Scienze e Lettere.)

Smith, E. K. M., and Samuel, P. D. (1970). Abnormalities in the sodium pump of erythrocytes from patients with hyperthyroidism. Clin. Sci., 38, 49-00.

Smith, E. K. M., and Welt, L. G. (1967). A reversible defect of membrane ATPase in the red cells of uremic patients. (Abstr.) Clin. Res., 15, 51.
Sodi-Pallares, D., Bisteni, A., Medrano, G. A., Micheli, A., de Ponce Léun J. de, Calva, E., Fishleder, B. L., Testelli, M. R., and Miller, B. L. (1966). The polarizing treatment in cardiovascular conditions. Experimental basis and clinical applications. In Electrolytes and Cardiovascular Diseases, vol. 2, edited by E. Bajusz, p. 198. Karger, Basel.

Sodi-Pallares, D., Ponce de Léon. J., de Bisteni, A., and Medrano, G. A. (1969). Potassium, glucose, and insulin in myocardia infarction. Lancet, 1, 1315-1316.

Stein, W. D. (1967). The Movement of Molecules Across Cell Membranes. Academic Press, New York and London.

Stoner, H. B., and Threlfall, C. J. (1960). The effect of limb ischaemia on carbohydrate distribution and energy transformation. In The Biochemical Response to Injury, edited by H. B. Stoner and C. J. Threlfall, pp. 105-128. Blackwell, Oxford.

Tosteson, D. C. (1964). Regulation of cell volume by sodium and potassium transport. In The Cellular Functions of Membrane Transport, pp. 3-22. Prentice Hall.

Tosteson, D. C., and Hoffman, J. F. (1960). Regulation of cell volume by active cation transport in high and low potassium sheep red cells. J. gen. Physiol., 44, 169-194.

Trémolière, S. J., and Derache, R. (1960). Metabolisme des composés phosphorés et specialement des nucléotides dans le tissu traumatisé. In The Biochemical Response to Injury. edited by H. B. Stoner and C. J. Threlfall, p. 23. Blackwell, Oxford.

Wade, O. L., and Bishop, J. M. (1962). Cardiac Output and Regional Blood Flow. Blackwell Scientific Publications, Oxford.

Welt, L. G., Sachs, J. R., and McManus, T. J. (1964). An ion transport defect in erythrocytes from uremic patients. Trans. Ass. Amer. Phycns, 77, 169-181.

Welt, L. G., Smith, E. K. H., Dunn, M. J., Czerwinski, A., Proctor, H., Cole, C., Balfe, J. W., and Gitelman, H. J. (1967). Membrane transport defect: the sick cell. Trans. Ass. Amer. Phycns, 80, 217-226.

Wollenberger, A., and Krause, E. G. (1968). Metabolic control characteristics of the acutely ischemic myocardium. Amer. J. Cardiol, 22, 349-359.

Woodbury, J. W. (1963). Interrelationships between ion transport mechanisms and excitatory events. Fed. Proc., 22, 31-35.

Woodbury, J. W. (1965). The cell membrane: ionic and potential gradients and active transport. In Physiology and Biophysics, edited by T. C. Ruch and H. D. Patton, pp. 1-25. Saunders, Philadelphia and London.

Wynn, V., and Houghton, B. J. (1957). Observations in man upon the osmotic behaviour of the body cells after trauma. Quart. J. Med. (N.S.), 26, 375-392.

Wynn, V., and Rob, C. G. (1954). Water intoxication: differential diagnosis of the hypotonic syndromes. Lancet, 1. 587-594. 